\title{
MOLECULAR APPROACH TO DETERMINE THE HOT AND COLD TEMPERAMENTS IN PLANTS ACCORDING AVICENNA CONCEPTS, THE ROLE OF MAGNESIUM
}

\author{
M. SHAROFOVA ${ }^{1,2}$, I. ALDYBIAT ${ }^{3}$, SH. SAGDIEVA ${ }^{1}$, N. BURKHONOVA ${ }^{1}$, YU. NURALIEV ${ }^{2,4}$, F. RAHIMI ${ }^{1}$, M. MIRSHAHI ${ }^{1,3}$ \\ 1 Research Center for Innovative Technologies, Academy of Sciences of the Republic of Tajikistan, Dushanbe, Republic of Tajikistan \\ 2 Institute of Avicenna's Medicine and Pharmacology, Dushanbe, Republic of Tajikistan \\ 3 University of Sorbonne Paris Cité-Paris 7, Lariboisière Hospital, INSERM U965, 75010 Paris, France \\ 4 Central Scientific-Research Laboratory, Avicenna Tajik State Medical University, Dushanbe, Republic of Tajikistan
}

Background: The molecular approach of millenary notion about hot and cold temperaments (mizaj) in plants according to Avicenna concepts is not investigated. The aim of this study is to analyze the correlation between mizaj property of plants from the Tajikistan area and their amount/quality of metal.

Methods: We analyzed the presence of several metals that implicated in body's homeostasis integrity, such as sodium, potassium, calcium, and magnesium, in several edible plants $(n=23)$ from different regions in Tajikistan. Samples $(n=43)$ of plant's parts including seeds, flower, leaf, stem and root were analyzed for their elements' composition using Energy Dispersive X-Ray Analysis (EDX) which incorporates Scanning Electron Microscopy (SEM).

Results: We didn't find any correlation between the area of the collected samples and the amount of metal absorbance by the plants. The metals distributions of plant's parts varied from one to the other. In this study, we found strict correlation between the amount of magnesium and the temperament properties of the plants reported by Avicenna. The magnesium was detected in high amount in Achillea millefolium L., Rosa canina L., Coriandrum sativum L., Foeniculum vulgare Mill. and Nigella sativa L.

Conclusions: The presence of high concentration of magnesium in the edible plants can be considered as a metal contribution (factor) in hot mizaj property and may lead to energy regeneration and wellbeing after consumption. Key words: Metal, hot and cold nature, plants, Avicenna, magnesium, Tajikistan.

For citation: Sharofova M, Aldybiat I, Sagdieva Sh, Burkhonova N, Nuraliev Yu, Rahimi F, Mirshahi M. Molecular approach to determine the hot and cold temperaments in plants according Avicenna concepts, the role of magnesium. Vestnik Avitsenny [Avicenna Bulletin]. 2018;20(4):421-6. Available from: http:// dx.doi.org/10.25005/2074-0581-2018-20-4-421-426

\section{МОЯЕКУ ЯЯРНЫЙ ПОДХОД В ОПРЕДЕЯЕНИИ «ГОРЯЧЕЙ» И «ХОЯОДНОЙ» НАТУР РАСТЕНИЙ В СООТВЕТСТВИИ С КОНЦЕПЦИЯМИ АВИЦЕННЫ, РОЛЬ МАГНИЯ}

\section{М. ШАРОФОВА ${ }^{1,2}$, И. АДДИБИАТ ${ }^{3}$ Ш. САГДИЕВА ${ }^{1}$, Н. БУРХОНОВА ${ }^{1}$, Ю. НУРАДИЕВ ${ }^{2,4}$, Ф. РАХИМИ}

1 Исследовательский центр инновационных технологий при Академии наук Республики Таджикистан, Душанбе, Республика Таджикистан

2 Институт медицины Авиценны и фармакологии, Душанбе, Республика Таджикистан

3 Университет Париж Сорбонна, Госпиталь Ларибуазьер, Париж, Франция

4 Центральная научно-исследовательская лаборатория, Таджикский государственный медицинский университет им. Абуади ибни Сино, Душанбе,

Республика Таджикистан

Молекулярный подход к концепции Авиценны о «горячем» и «холодном» мизаджах растений тысячелетней давности всё ещё не исследован. Цель: анализ взаимосвязей между «мизаджами» растений, произрастающих на территории Таджикистана, и содержанием (количеством/ качеством) металлов.

Материал и методы: проанализированы присутствие нескольких элементов, таких как натрий, калий, кальций и магний, которые принимают участие в процессах гомеостаза организма, в составе нескольких лекарственно-пищевых растений (n=23) из разных регионов Таджикистана. В образцах ( $\mathrm{n=43)}$ отдельных частей растений (семена, цветки, листья, стебли и корни) был изучен состав элементов с использованием энергодисперсионного рентгеновского анализа на сканирующем электронном микроскопе.

Результаты: не обнаружено никакой корреляции между регионом сбора и количеством металлов, поглощённых растениями. Распределение металлов в различных частях растений варьировало. В этом исследовании обнаружена строгая корреляция между количеством магния и особенностями натуры растений, описанных Авиценной. Магний был обнаружен в большом количестве в Achillea millefolium L. (тысячелистник), Rosa canina L. (шиповник), Coriandrum sativum L. (кориандр), Foeniculum vulgare Mill. (фенхель) и Nigella sativa L. (чернушка).

Заключение: высокая концентрация магния в лекарственно-пищевых растениях может быть характерным свойством «горячего» мизаджа, и при их употреблении способствовать восстановлению энергетического потенциала и оздоровлению организма.

Ключевые слова: металл, горячая и холодная натура, растение, Авиценна, магний, Таджикистан.

Для цитирования: Sharofova M, Aldybiat I, Sagdieva Sh, Burkhonova N, Nuraliev Yu, Rahimi F, Mirshahi M. Molecular approach to determine the hot and cold temperaments in plants according Avicenna concepts, the role of magnesium. Vestnik Avitsenny [Avicenna Bulletin]. 2018;20(4):421-6. Available from http://dx.doi.org/10.25005/2074-0581-2018-20-4-421-426

\section{INTRODUCTION}

According to Avicenna, the internal properties of the alimentations varied in temperaments and corresponded to both kinds of cold and hot properties. The balance of cold/hot was presented as a biological law in the Canon of medicine [1]. Disruption of this balance may stimulate metabolic syndrome [2]. There is little information about molecular as well as physiological basis of these concepts. We are interested in investigating the role of metals in some plants identified as hot or cold according to Avicenna.

Certain elements have long been recognized (known) to have important biological functions primarily as a consequence of nutritional investigations [3-5]. Thus, the absence of a specific, 
essential mineral from the diet of an organism invariably leads to a deficiency state characterized by metabolic abnormalities with altered body homeostasis. Because such metals are usually present in tissues in very small amounts, it was reasonable to suspect that they might play an important role as catalyst via participating in enzymatic reactions. The discovery of metallo-enzymes, however, required the availability of accurate, sensitive and analytical methodology. As a consequence, the unequivocal demonstration of a role for metals, in enzyme action, is of relatively recent vintage.

At present, reliable measurements of small concentrations of metals in tissues, cells, subcellular particles, body fluids and bio macromolecules can be performed among other methods by colorimetry, fluorimetry, polarography, emission spectrometry with spark, flame or plasma excitation sources, $x$-ray and atomic fluorescence, atomic absorption and neutron activation analysis. Metals that have been detected by such techniques and currently known to be components of metalloenzymes include manganese and zinc in various enzyme activity, cobalt (carboxylation), copper (oxidoreduction), iron (oxido-reduction), molybdenum (oxido-reduction), nickel (urease), selenium (peroxidase). Among these metals, over 300 enzymes require the presence of magnesium ions for their catalytic action [6], including all enzymes utilizing or synthesizing ATP [7] or those that use nucleotides to synthesize DNA and RNA [8, 9].

In central Asia, habitually, the medical properties of the plants or their fruits were also classed in the two temperaments (mizaj) cold and hot. Based on the Canon of Avicenna, several local investigations allowed identifying the medical possession of regional plants as well as their categories [10]. In recent study, we reported the presence of first main series of transition elements from atomic number of 22 to 29 such as titanium, vanadium, chromium, manganese, iron, cobalt, nickel and copper in the plants from Tajikistan areas [11] and observed that the majority of plants with hot mizaj property accumulate more metals when they compared with cold mizaj plants. Over all, the molecular approach of this milliner notion is not investigated.

The aim of this study is to analyze the correlation between mizaj property of plants and their amount of metal quality in medicinal plants.

\section{- MATERIAL AND METHODS}

\section{Plants diversity and regions of collect}

23 different plants according to their cold and hot properties were collected in several regions in Tajikistan. Their classification and distribution in Tajikistan area is presented in table.

\section{- Plant collection and extraction}

All collected plants' parts such as flower, leaf, stem and root were collected and delicately washed by abundant distilled water and were dried in the dark for five weeks. The dried plant parts were grounded using a blender apparatus. The powders were kept in a special dish and sent for extraction to the University of Sorbonne Paris Cité-Paris 7, Lariboisière Hospital, INSERM U965, 75010 Paris, France.

Table Hot $^{*}$ and cold** temperament plants reported by Avicenna***

\begin{tabular}{|c|c|c|c|c|}
\hline № & Plants & $\begin{array}{l}\text { Regions of } \\
\text { collect }\end{array}$ & Date of collect & Altitude (m) \\
\hline \multirow[t]{2}{*}{1} & $\begin{array}{l}\text { Anethum graveolens L.* } \\
\text { (aboveground part) }\end{array}$ & Nourabad & July, 2017 & $800-1800$ \\
\hline & Anethum graveolens L. (seeds) & Faizabad & August - September, 2016 & $1500-1630$ \\
\hline 2 & Thymus seravshanicus Klok.* & Nourabad & July, 2017 & $1700-3600$ \\
\hline 3 & Achillea millefolium L.* & Nourabad & July, 2017 & $1800-2400$ \\
\hline 4 & Tanacetum pseudoachillea C. Winkl.* & Nourabad & July, 2017 & $1600-3000$ \\
\hline 5 & Peganum harmala L.* & Nourabad & July, 2017 & $450-3700$ \\
\hline 6 & Origanum tyttanthum Gontsch.* & Nourabad & July, 2017 & $800-2700$ \\
\hline 7 & Hypericum perforatum L.* & Nourabad & July, 2017 & $700-3000$ \\
\hline 8 & Ribes meyeri Maxim.* & Rasht & 2016 & $2000-4300$ \\
\hline 9 & Matricaria recutita L.* & Ramit & June, 2017 & $400-1500$ \\
\hline 10 & Mentha arvensis L.* & Ramit & June, 2017 & $850-2000$ \\
\hline 11 & Prunus armeniaca L.** & Gonchi & June, 2017 & $800-2480$ \\
\hline 12 & Prunus cerasifera Ehrh.** & Gonchi & June, 2017 & $400-2600$ \\
\hline 13 & Berberis nummularia Bunge. ${ }^{* *}$ & Condara & 2016 & $1500-2500$ \\
\hline 14 & Rhus coriaria L.** & Ramit & 2016 & $1000-1800$ \\
\hline 15 & Rheum maximoviczii Losinsk. ${ }^{* *}$ & Varzob & 2016 & $1100-3900$ \\
\hline 16 & Rosa canina $\mathrm{L}^{*}$. & Varzob & 2016 & $1000-2200$ \\
\hline 17 & Glycyrrhiza glabra L.* & Shahritous & 2016 & $350-1600$ \\
\hline 18 & Coriandrum sativum L. * & Faizabad & 2016 & $400-1200$ \\
\hline 19 & Plantago lanceolata L.** & Ramit & 2016 & $600-3400$ \\
\hline 20 & Nigella sativa L.* & Zafarabad & 2016 & $1200-2000$ \\
\hline 21 & Foeniculum vulgare Mill.* & Varzob & 2016 & $900-2000$ \\
\hline 22 & Helichrysum thianschanicum Regel.* & Varzob & 2016 & $1800-3100$ \\
\hline 23 & Citrus limon (Citrus Meyeri Yu.Tanaka)** & Dushanbe & 2017 & $400-1200$ \\
\hline
\end{tabular}

***Avicenna «Works». Volume 13. Canon of medical science: The second book. Dushanbe: Donish; 2012. 958 p. Note: The numbers 8,15 and 22 are not noted in the Avicenna's works. In the same book of Avicenna page 418-420, Coriandrum sativum L. was classed among of cold temperament plants, and explain that Claudius Galenus considered this plant as hot temperament. 
Plant extraction was performed using $10 \mathrm{gr}$. of plant powder in $100 \mathrm{ml}$ ethanol solution 70\% diluted in distilled water and incubated in obscurity condition for 3 weeks under mixture apparatus (agitation). The plant powder solutions were centrifuged (5000 T/ min for 30 minutes) and the supernatants were collected. The soluble plant extracts were dried and used for metal analysis.

\section{Metal analysis}

Multi-walls slide (Fig. 1a) was used to deposit 10 to $20 \mu \mathrm{l}$ of each sample. Slide then left to dry and prepared for analysis. Slide was coated by carbon layer to avoid the overcharge of the image (Fig. 1b) then EDX spectrum (Zeiss Ultra 55 FEG SEM with GEMIN, S260 CAMBRIDGE scanning electron microscopy) was used (Fig. 1c) to read the continent of the sample. For each sample, two to three zones were measured. The final of 2 to 3 data was expressed as the atomic and mass percent.

Energy Dispersive X-Ray Analysis (EDX) is an $\mathrm{x}$-ray technique used to identify the elemental composition of materials. Applications include materials and product research, troubleshooting, deformulation, and more. For this study, EDX system was attached to Electron Microscopy instruments (Scanning Electron Microscopy (SEM). Energy Dispersive X-ray Spectroscopy is based on the detection of characteristic $x$-rays emitted of an element as a result of the de-excitation of core electron holes created by a high energy electron beam. An electron from a higher binding energy electron level falls into the core hole and an x-ray with the energy of the difference of the electron level binding energies is emitted. Due to the quantization of electron energy levels, the emitted characteristic $x$-ray energies for elements will generally be different from one element to another with only a few spectral peaks overlapping. The normal electron beam of a scanning electron microscope is used as the excitation source. The addition of an energy measuring x-ray detector with a thin, low mass element window on a SEM enables EDX for all elements from carbon on up in atomic mass. A spectrum consists of all $\mathrm{x}$-rays characteristic emitted by the present elements in the sample on a continuous background due to Bremsstrahlung $\mathrm{x}$-ray emission caused by the deceleration of the high energy electrons of the electron beam in the sample.

\section{RESULTS AND DISCUSSION}

Thymus seravshanicus Klok. was an illustrative example from all studied plants presented for flowers (Fig. 2a), roots (Fig. 2b) and a

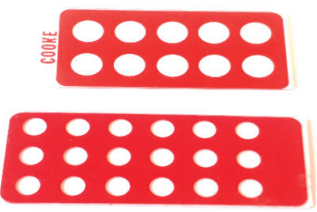

b

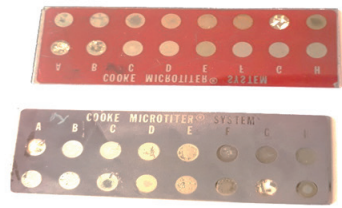

c

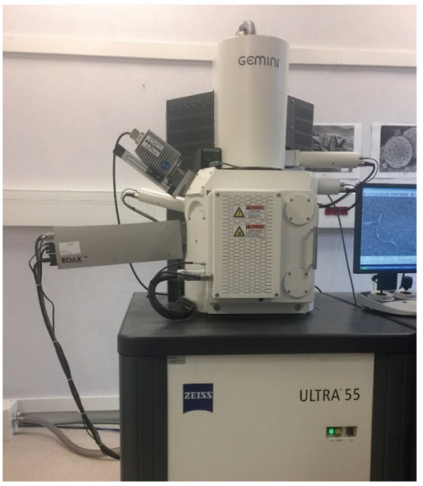

Fig. 1 Samples preparation for scanning electronical microscopy SEM: multi-wall slide form (a); carbon layer coating the samples (b); scanning electronical microscopy machine (c). stems (Fig. 2c). The three-wire specimen shown (a) was created to illustrate specific capabilities of the combined SEM/EDX system. This includes SEM imaging by secondary electrons and backscattered electrons in combination with compositional analysis and elemental mapping using EDX. Three parts of each sample were presented here and in each part, the semi-quantitative elemental composition information was performed for several metals that were found in $2-3 \times 1000 \mathrm{~nm}$ depth. X-rays that have sufficient energy to escape the material surface can be detected as resulting in a spectrum of peaks with characteristic energies. The elements present in each zone showed in (1-3) and the amount of detected elements are presented in Fig. $2 \mathrm{~b}$. $\mathrm{Na}, \mathrm{Mg}, \mathrm{Al}, \mathrm{K}$, and $\mathrm{Ca}$ are the main metals and also $\mathrm{C}, \mathrm{O}, \mathrm{Si}$ and $\mathrm{Cl}$ elements were found. In this study, we focused on the presence of magnesium in the plants.

The amount of the metals $\mathrm{Mg}^{2+}$ detected for 43 parts from 23 plants collected from different regions in Tajikistan presented in Fig. 3.

The findings indicated that the amount of metals are varied according to plant's parts. In our example (Thymus seravshanicus Klok.), the analysis showed that the amount of the elements was not the same in roots compared to the flowers and stems. The first five plants with high amount of magnesium such as Achillea millefolium L., Rosa canina L., Coriandrum sativum L., Foeniculum vulgare Mill., Nigella sativa L. exhibited low amount of potassium and vice-versa for magnesium.

In this study, we found strict correlation between the amount of magnesium and temperament properties of the plants. In parallel, in other study, we analyzed the presence of copper and zinc and we did not find any correlation between amount of these metals and temperament properties (results not shown).

$\mathrm{Mg}^{2+}$ is the fourth-most-abundant metal ion in cells and the most abundant free divalent cation. As a result, it is deeply and intrinsically woven into cellular metabolism. Indeed, $\mathrm{Mg}^{2+}$-dependent enzymes appears in virtually every metabolic pathway: specific binding of $\mathrm{Mg}^{2+}$ to biological membranes is frequently observed. $\mathrm{Mg}^{2+}$ is also used as a signaling molecule, and much of nucleic acid biochemistry requires $\mathrm{Mg}^{2+}$, including all reactions that require release of energy from ATP [12-14], which is called ATP and is often actually Mg-ATP. In nucleotides, the triplephosphate moiety of the compound is invariably stabilized by association with $\mathrm{Mg}^{2+}$ in all enzymatic processes [15].

Our results demonstrated that magnesium can be a candidate for hot temperaments of plants used currently as edible vegetable. The human body contains around $25 \mathrm{gr}$. of magnesium, 50 to 60 percent of which is stored in the skeletal system. The rest is present in muscle, soft tissues, and bodily fluids. Magnesium plays a role in over 300 enzymatic reactions within the body [16-21], including the metabolism of food, synthesis of fatty acids and proteins, and the transmission of nerve impulses. Magnesium is important for bone formation. It helps assimilate calcium into the bone and plays a role in activating vitamin $D$ in the kidneys. Vitamin $D$ is also essential for healthy bones [22]. Optimal magnesium intake is associated with greater bone density, improved bone crystal formation, and a lower risk of osteoporosis in women after menopause. Without magnesium, a high intake of calcium can increase the risk of arterial calcification and cardiovascular disease, as well as kidney stones. Thus, taking calcium supplements should also take magnesium to ensure their calcium intake is properly metabolized.

Magnesium plays an important role in carbohydrate and glucose metabolism, so magnesium status can also impact the risk of diabetes [23]. Several studies have associated a higher intake of magnesium with a lower risk of diabetes. For every $100 \mathrm{mg}$ per day increase in magnesium intake, up to a point, the risk of developing type 2 diabetes decreases by approximately 15 percent. Low magnesium levels were linked to impaired insulin secretion and lower insulin sensitivity. According to the National Institutes of Health (NIH), the American Diabetes Association notes that further evidence is needed before magnesium can be routinely used for glycemic control in patients with diabetes. In previous study, we reported the influence of cold temperament diet on metabolic 
Fig. 2A

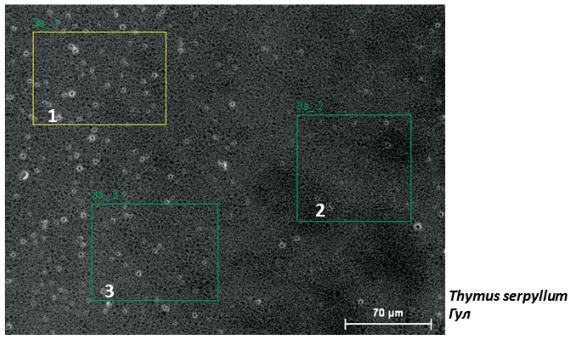

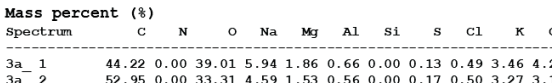

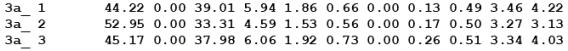

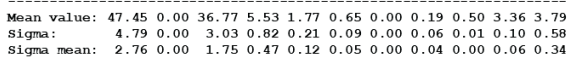

Fig $2 \mathrm{~B}$
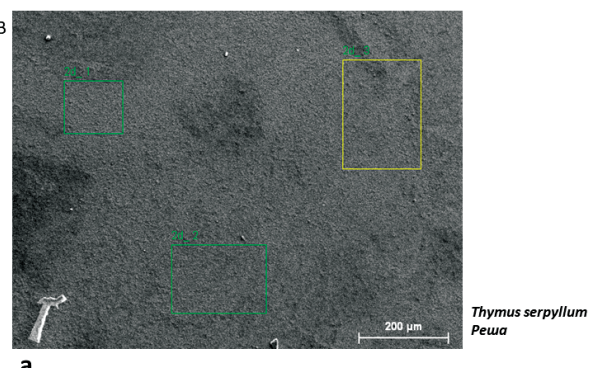

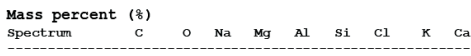

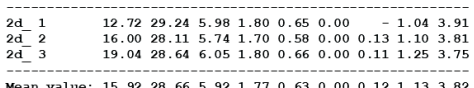

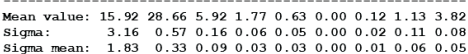

sigma

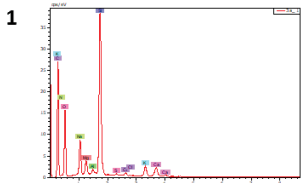

2

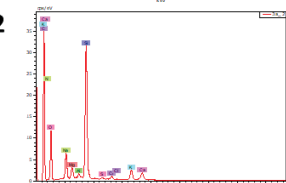

3

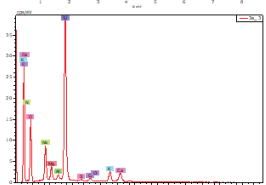

1

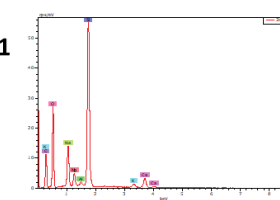

2

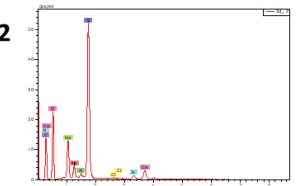

3

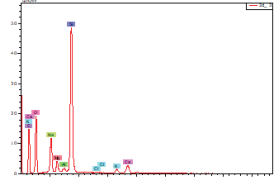

disorders and diabetes induction in animal models [24]. In parallel, magnesium is necessary to maintain the health of muscles, including the heart, and for the transmission of electrical signals in the body. These observations suggest the crucial role of magnesium in human
Fig. 2 Thymus seravshanicus Klok. The highlighted rectangles in the inset image show the selected EDX inspection field (a). The detected spectrum and tabulated results revealed that $\mathrm{Na}, \mathrm{Mg}, \mathrm{Al}, \mathrm{K}$, and $\mathrm{Ca}$ are the main elements present with a variation of $\mathrm{Mg}$ and $\mathrm{K}$ amounts in each part of Thymus seravshanicus Klok. In this sample $\mathrm{C}, \mathrm{O}, \mathrm{S}$, and $\mathrm{Cl}$ also presented. The relative amount of each detected metal is presented in a table in corresponding to the samples. In this study $15 \mathrm{KeV}$ (in X axe) was used for detection of mineral composition in each simple and the \% of minerals for different atom in each rectangle were expressed.
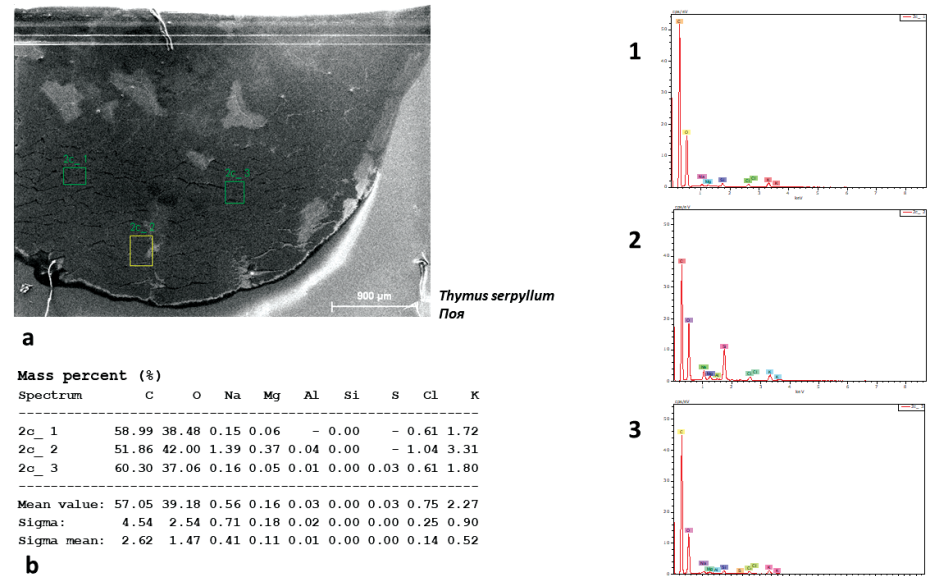

3

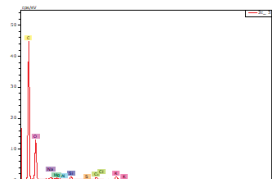

body homeostasis especially in energy production processes. Presence of high concentration of magnesium in the edible plants with hot mizaj properties may contribute to energy regeneration and wellbeing after their consumption.

\section{Mg Mass percent (\%)}

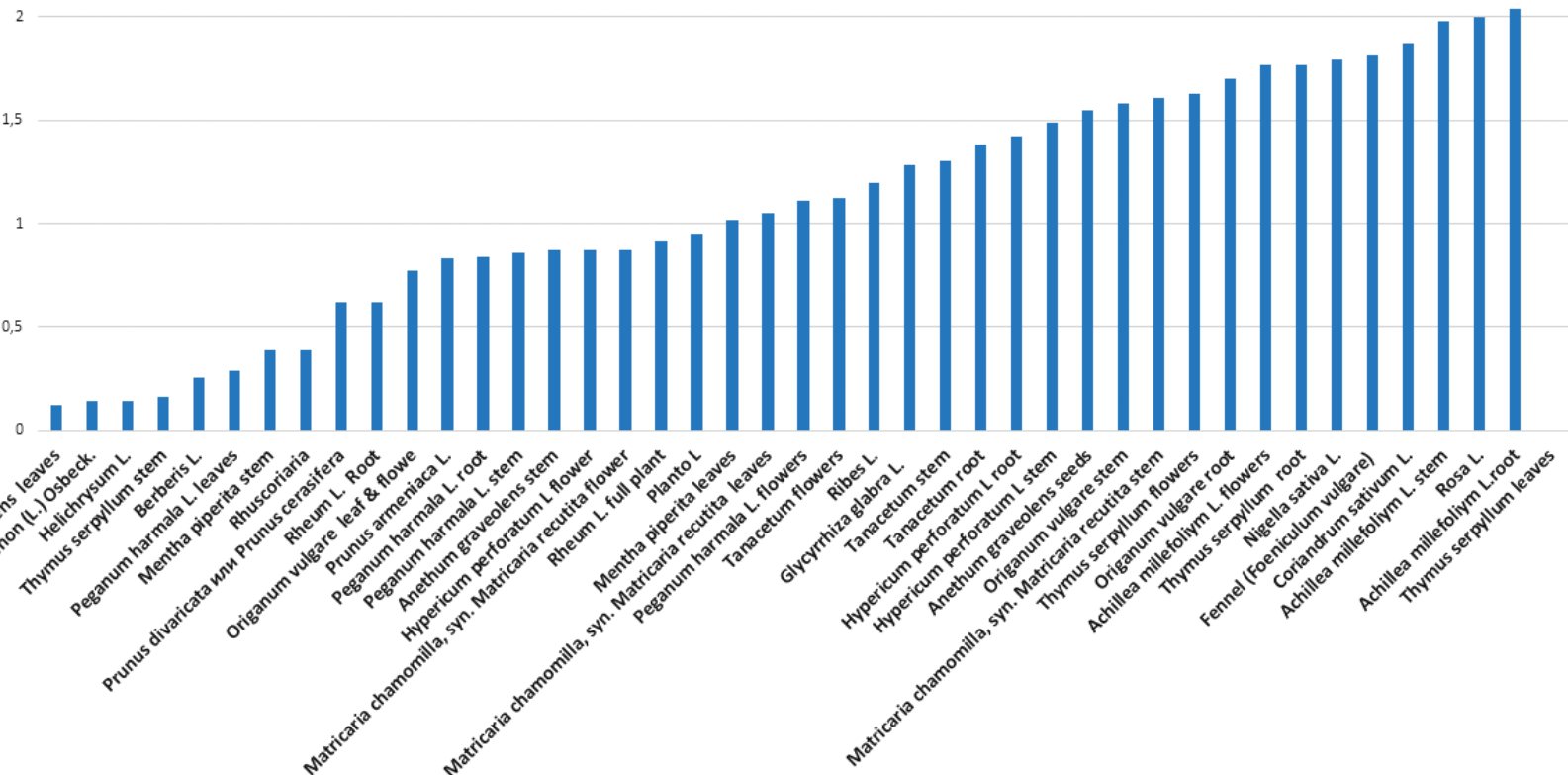




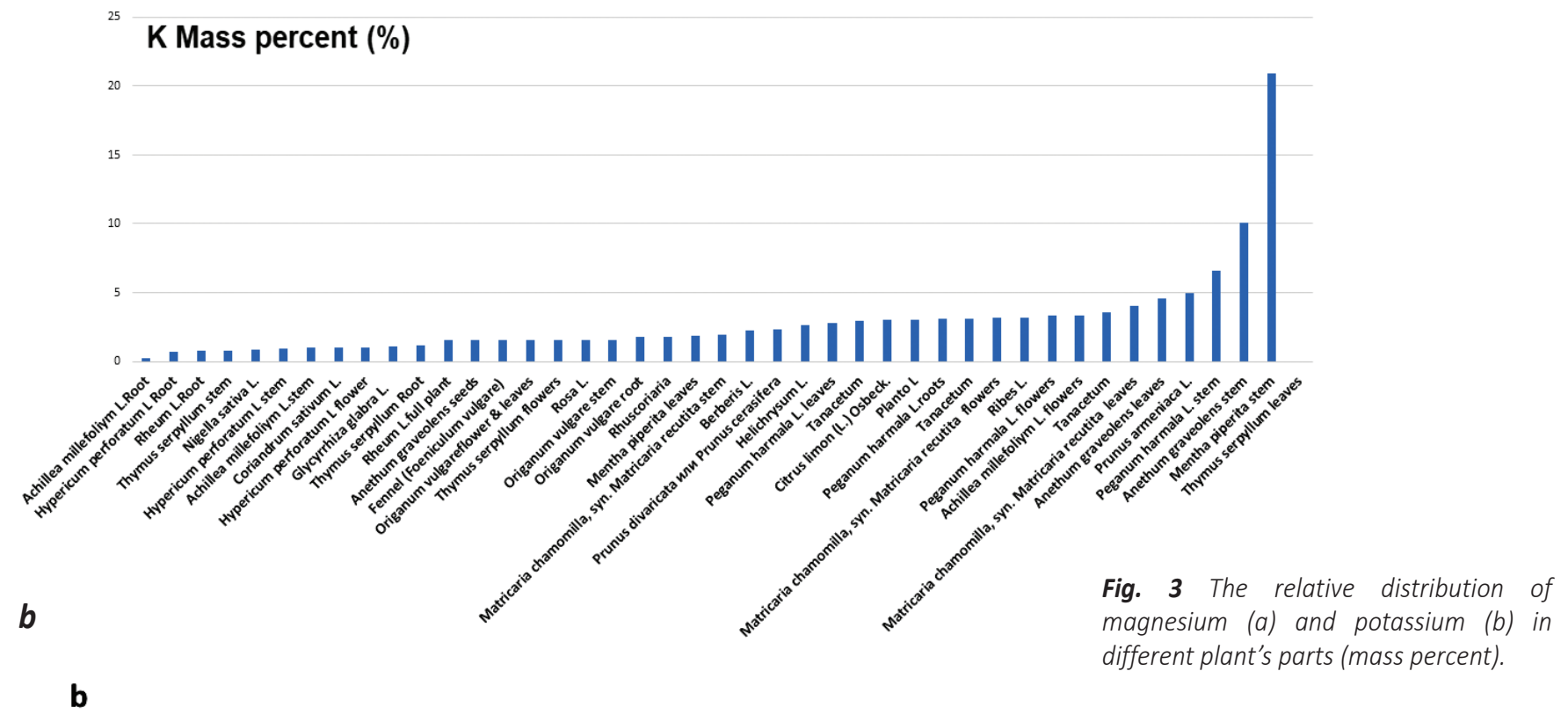

Deficiency of magnesium is linked with the symptom as numbness and tingling, muscle cramps, seizures, personality changes, heart rhythm changes and spasms. Deficiency also is associated with insulin resistance, metabolic syndrome, coronary heart disease, and osteoporosis. It can lead to low calcium or low potassium levels in the blood. The use of the plants with hot mizaj property can be interesting for treated magnesium deficiency as a traditional medication.

\section{REFERENCES}

1. Avicenna "Works». Volume 13. Canon of medical science: The second book. Dushanbe: Donish; 2012. 958 p.

2. Sharofova M, Nuraliev Yu, Sukhrobov P, Sagdieva Sh, Dushenkov V. Can Avicenna help manage the diabetes epidemic in Central Asia? Central Asian Journal of Medical Sciences. 2017;3(3):200-20.

3. Lehninger AL. Bole of metal ions in enzyme systems. Physiol Bev. 1950;30:393429.

4. Li TK, Vallee BL. Trace elements, Section B. The biochemical and nutritional role of trace elements. In: Goodhart RS, Shils ME (eds.). Modem nutrition in health and disease. Philadelphia, USA: Lea and Febiger; 1973. p. 372-399.

5. Biordan JF, Vallee BL. The functional role of metals in metalloenzymes. Protein-metal interactions. Friedman M. (ed). Advances in Exp Med Biol. 1974;48:33-58

6. Li HC. Activation of brain calcineurin phosphatase towards nonprotein phosphoesters by $\mathrm{Ca}^{2+}$, calmodulin, and $\mathrm{Mg}^{2+}$. J Biol Chem. 1984;259(14):8801-7.

7. Elnatan D, Agard DA. Calcium binding to a remote site can replace magnesium as cofactor for mitochondrial Hsp90 (TRAP1) ATPase activity. J Biol Chem. 2018;293(35):13717-24. Available from: http://dx.doi.org/10.1074/jbc. RA118.003562.

8. Parsiegla G, Noguere C, Santell L, Lazarus RA, Bourne Y. The structure of human DNase I bound to magnesium and phosphate ions points to a catalytic mechanism common to members of the DNase I-like superfamily. Biochemistry. 2012;51(51):10250-8. Available from: http://dx.doi. org/10.1021/bi300873f

9. Inoue A, Takagi $Y$, Taira K. Importance of magnesium ions in the mechanism of catalysis by a hammerhead ribozyme: strictly linear relationship between the ribozyme activity and the concentration of magnesium ions. Magnes Res. 2003;16(3):210-7.

10. Sharofova MU, Nuraliev YuN, Sagdieva ShS, Sukhrobov PSh. Mekhanizm diabetogeneza po Avitsenne i diabetogennye faktory riska [Diabetes genesis mechanism by Avicenna and risk factors]. Obzory po klinicheskoy farmakologii i lekarstvennoy terapii. 2018;16(2):74-9.
11. Sharofova MU, Sagdieva ShS, Abdulloev SF, Maslov VA, Rahimi F, Mirshahi $M$. To the question of the content of transition elements in plant structures. Reports of the Academy of Sciences of the Republic of Tajikistan. 2018;61(4):350-9.

12. Van Nostrand's Scientific Encyclopedia, magnesium (in biological systems). 2006. Available from: http://dx.doi.org/10.1002/0471743984.vse4741.

13. Leroy J. Necessite du magnesium pour la croissance de la souris. Comptes Rendus des Séances de la Société de Biologie. 1926;94:431-3.

14. Lusk JE, Williams RJP, Kennedy EP. Magnesium and the growth of Escherichia coli. Journal of Biological Chemistry. 1968;243(10):2618-24.

15. Labyntseva RD, Slinchenko NM, Veklich TO, Rodik RV, Cherenok SO, Bolko $\mathrm{VI}$, et al. Comparative study of calixarene effect on $\mathrm{Mg}^{2+}$-dependent ATPhydrolase enzymatic systems from smooth muscle cells of the uterus. Ukr Biokhim Zh. 2007;79(3):44-54.

16. Elin RJ. Magnesium: the fifth but forgotten electrolyte. Am J Clin Pathol. 1994;102:616-22. Available from: http://dx.doi.org/10.1093/ajcp/102.5.616.

17. Li FY, Chaigne-Delalande B, Kanellopoulou C. Second messenger role for $\mathrm{Mg}^{2+}$ revealed by human T-cell immunodeficiency. Nature. 2011;475:471-6. Available from: http://dx.doi.org/10.1038/nature10246.

18. Fawcett WJ, Haxby EJ, Male DA. Magnesium: physiology and pharmacology. Br J Anaesth. 1999;83:302-20. Available from: http://dx.doi.org/10.1093/ $\mathrm{bja} / 83.2 .302$.

19. Shechter M, Kaplinsky E, Rabinowitz B. The rationale of magnesium supplementation in acute myocardial infarction. A review of the literature. Arch Intern Med. 1992;152:2189-96. Available from: http://dx.doi. org/10.1001/archinte.1992.00400230015003.

20. Montes de Oca A, Guerrero F, Martinez-Moreno JM. Magnesium inhibits Wnt/beta-catenin activity and reverses the osteogenic transformation of vascular smooth muscle cells. PLoS One. 2014;9:e89525. Available from: http://dx.doi.org/10.1371/journal.pone.0089525.

21. Rude RK. Magnesium deficiency: a cause of heterogeneous disease in humans. J Bone Miner Res. 1998;13:749-58. Available from: http://dx.doi. org/10.1359/jbmr.1998.13.4.749. 
22. Alfrey AC, Miller NL. Bone magnesium pools in uremia. J Clin Invest. 1973;52:3019-27. Available from: http://dx.doi.org/10.1172/JCI107500.

23. Fang $\mathrm{X}$, Han H, Li M, Liang C, Fan Z, Aaseth J, et al. Dose-response relationship between dietary magnesium intake and risk of type 2 diabetes mellitus:
A systematic review and meta-regression analysis of prospective cohort studies. Nutrients. 2016;8(11):739.

24. Sharofova M, Nuraliev Yu, Ganiev Kh, Suhrobov P, Zubaydova T, Samandarov $\mathrm{N}$, Mirshahi M. Acid dietary as diabetogenic risk factors. IESC Res J. 2016;2(9):51-6.

\section{(i) СвеДЕНИЯ ОБ АвТОРАХ}

Шарофова Мижгона, кандидат медицинских наук, заведующая лабораторией биотехнологий Исследовательского центра инновационных технологий при Академии наук Республики Таджикистан; директор Института медицины Авиценны и фармакологии

Алдибиат Иман, PhD, научный сотрудник, Университет Париж Сорбонна, Госпиталь Ларибуазьер

Сагдиева Шоиста, кандидат медицинских наук, старший научный сотрудник лаборатории биологических наук Исследовательского центра инновационных технологий при Академии наук Республики Таджикистан

Бурхонова Нигора, младший научный сотрудник лаборатории биотехнологий Исследовательского центра инновационных технологий при Академии наук Республики Таджикистан

Нуралиев Юсуф, доктор медицинских наук, почётный профессор Центральной научно-исследовательской лаборатории, Таджикский государственный медицинский университет им. Абуали ибни Сино; ко-директор Института медицины Авиценны и фармакологии

Рахими Фарход, доктор физико-математических наук, профессор, академик Академии наук Республики Таджикистан, Президент Академии наук Республики Таджикистан

Миршахи Масуд, MD, PhD, профессор, Университет Париж Сорбонна, Госпиталь Ларибуазьер

Информация об источнике поддержки в виде грантов, оборудования, лекарственных препаратов

Финансовой поддержки со стороны компаний-производителей лекарственных препаратов и оборудования авторы не получали.

Конфликт интересов: отсутствует.

\section{ВКЛАД АВТОРОВ}

Разработка концепции и дизайна исследования: ШМ, ММ

Сбор материала: ШМ, АИ, СШ, БН, ММ

Статистическая обработка данных: ШМ, СШ, БН

Анализ полученных данных: ШМ, СШ, БН

Подготовка текста: МM

Редактирование: ШМ, АИ, НЮ, РФ, ММ

Общая ответственность: ММ

\section{АДРЕС ДЛЯ КОРРЕСПОНДЕНЦИИ:}

Massoud Mirshahi MD, PhD

Université de Sorbonne Paris Cité

UMR Paris 7, INSERM U965

Carcinose, Angiogenèse et

Recherche Translationnelle

L'Hôpital Lariboisière

$41 \mathrm{Bd}$ de la Chapelle

75010, Paris, France

Tel.: 0033153216775

Fax: 0033153216739

E-mail: massoud.mirshahi@inserm.fr

\section{(i) author information}

Sharofova Mizhgona, Candidate of Medical Sciences, Head of the Laboratory of Biotechnology, Research Center for Innovative Technologies, Academy of Sciences of the Republic of Tajikistan; Director of the Institute of Avicenna's Medicine and Pharmacology

Aldybiat Iman, PhD, Post Doctorant in University of Sorbonne Paris Cité-Paris 7, Lariboisière Hospital

Sagdieva Shoista, Candidate of Medical Sciences, Senior Researcher of the Laboratory of Biological Sciences, Research Center for Innovative Technologies, Academy of Sciences of the Republic of Tajikistan

Burkhonova Nigora, Junior Researcher of the Laboratory of Biotechnology, Research Center for Innovative Technologies, Academy of Sciences of the Republic of Tajikistan

Nuraliev Yusuf, Doctor of Medical Sciences, Honorary Professor of the Central Scientific-Research Laboratory, Avicenna Tajik State Medical University; CoDirector of the Institute of Avicenna's Medicine and Pharmacology

Rahimi Farhod, Doctor of Physical and Mathematical Sciences, Professor, Academician and President of the Academy of Sciences of the Republic of Tajikistan

Mirshahi Massoud, Professor, MD, PhD, University of Sorbonne Paris CitéParis 7, Lariboisière Hospital, Member of the Academy of Sciences of the Republic of Tajikistan

Information about the source of support in the form of grants, equipment, drugs

The authors did not receive financial support from the companies producing medical drugs and manufacturing medical equipment

Competing interests: none

\section{AUTHOR CONTRIBUTIONS}

Conception and design: ShM, MM

Data collection: ShM, Al, SSh, BN, MM

Statistical analysis: ShM, SSh, BN

Analysis and interpretation: ShM, SSh, BN

Writing the article: MM

Critical revision of the article: ShM, Al, NYu, RF, MM

Overall responsibility: MM

$\checkmark$ ADDRESS FOR CORRESPONDENCE:

Massoud Mirshahi MD, PhD

Université de Sorbonne Paris Cité

UMR Paris 7, INSERM U965

Carcinose, Angiogenèse et

Recherche Translationnelle

L'Hôpital Lariboisière

$41 \mathrm{Bd}$ de la Chapelle

75010, Paris, France

Tel.: 0033153216775

Fax: 0033153216739

E-mail: massoud.mirshahi@inserm.fr 